\title{
Fat Replacers in Baked Food Products
}

\author{
Kathryn Colla $₫$, Andrew Costanzo $₫$ and Shirani Gamlath * \\ Centre for Advanced Sensory Sciences, School of Exercise and Nutrition Sciences, Deakin University, \\ 1 Gheringhap Street, Geelong 3220, Australia; k.colla@deakin.edu.au (K.C.); \\ andrew.costanzo@deakin.edu.au (A.C.) \\ * Correspondence: shirani.gamlath@deakin.edu.au; Tel.: +61-3-925-17267
}

Received: 15 October 2018; Accepted: 22 November 2018; Published: 25 November 2018

\begin{abstract}
Fat provides important sensory properties to baked food products, such as colour, taste, texture and odour, all of which contribute to overall consumer acceptance. Baked food products, such as crackers, cakes and biscuits, typically contain high amounts of fat. However, there is increasing demand for healthy snack foods with reduced fat content. In order to maintain consumer acceptance whilst simultaneously reducing the total fat content, fat replacers have been employed. There are a number of fat replacers that have been investigated in baked food products, ranging from complex carbohydrates, gums and gels, whole food matrices, and combinations thereof. Fat replacers each have different properties that affect the quality of a food product. In this review, we summarise the literature on the effect of fat replacers on the quality of baked food products. The ideal fat replacers for different types of low-fat baked products were a combination of polydextrose and guar gum in biscuits at 70\% fat replacement (FR), oleogels in cake at $100 \% \mathrm{FR}$, and inulin in crackers at $75 \% \mathrm{FR}$. The use of oatrim $(100 \% \mathrm{FR})$, bean puree $(75 \% \mathrm{FR})$ or green pea puree $(75 \% \mathrm{FR})$ as fat replacers in biscuits were equally successful.
\end{abstract}

Keywords: fat replacers; baked products; carbohydrates; gums; gels; whole foods

\section{Introduction}

Dietary fat has an important role within food matrices beyond basic nutrition. It contributes to many sensory and quality properties of a food including physical, textural and olfactory factors which all influence overall palatability. Many snack foods, in particular, rely on dietary fat to fulfil these palatable qualities in order to maintain consumer acceptance and consumption. The World Health Organisation [1], along with many national health authorities [2-5], recommends decreasing consumption of discretionary snack foods due to their poor nutritional content. Excess dietary fat intake, notably from discretionary snack foods, is one of the key contributors to excess energy intake and therefore weight gain [6]. Prevalence of overweight and obesity is rising worldwide $[7,8]$ which is cause for concern as obesity is associated with increased risk of cardiovascular disease [9], type 2 diabetes mellitus [10], and some cancers [11].

Despite consumer awareness and product labelling [12,13], consumption of snack foods is relatively high with little compensation for the increased energy intake [14-16]. Many promoters have been attributed to increased snack food intake, such as convenience, taste, marketing and pricing $[16,17]$. In order to respond to these recommendations and consumer demands, manufacturing companies are increasingly developing snacks which are more nutrient dense than traditional snacks such as chips and cakes, which are typically high in added fat, sugar and sodium. Some examples of these types of innovative snacks include yoghurts, bars, puddings, crackers and chips which contain popular health foods (or superfoods) such as seeds, nuts, ancient grains, other wholegrains, dietary fibres, legumes, fruits and vegetables. While many of these snacks may be high in protein and dietary 
fibre, many also typically contribute large amounts of fat, sugar and sodium to the consumers' diet [18]. Efforts must be made to develop appealing snacks which are both high in protein and dietary fibre while not contributing large amounts of sodium, sugar and fat. Snack food categories such as cakes and muffins are yet to see significant innovation in creating high protein or high fibre alternatives [16]. In addition, there are still limited reduced fat options of these baked products on the market, likely attributed to the technological difficulty in producing such products. Ultimately, there is a need to increase the number of nutritious snack options available that satisfy the above drivers, while reducing fat composition and therefore total energy intake. Baked snack foods that omit dietary fat as a "low-fat" alternative often have poor sensory properties, such as crumbliness, dryness, poor mouthfeel and overall reduced consumer acceptance [19-23]. A number of potential "fat replacers" have been purported in order to reduce the fat content in food matrices whilst maintaining the sensory properties that are usually attributed to dietary fat. Fat replacers are subcategorised as either fat substitutes or fat mimetics. Fat substitutes replicate the functional and sensory properties of fat in a food, usually contain no energy or less energy than fat, and may be used to replace some or all of the fat normally present in a product $[24,25]$. Fat mimetics are protein- or carbohydrate-based ingredients that are not used to fully substitute the use of fat, but rather replicate some of the properties that fat provides within a food [24,25]. Many baked products on the market currently utilise fat replacers in order to reduce the total energy or fat content whilst maintaining consumer acceptance. This review aims to summarise the current evidence for application of fat replacers in biscuits, crackers, muffins, cakes and bread, and their effect on quality and sensory properties.

\section{Application of Fat Replacers in Baked Products}

Fat replacers are defined by the American Dietetic Association as "an ingredient that can be used to provide some or all of the functions of fat, yielding fewer calories than fat" [24]. A wide range of products in the food industry uses fat replacers, some of which include meat, dairy and baked products [24]. It is important for product developers and food technologists to understand how different fat replacers influence the sensory and physical quality of snacks in order to guide the development of healthier alternative products. For example, in cakes, fat can contribute to increased leavening, tenderness and a finer crumb through a combined effect of trapping air cells during the creaming process [26]. This structure is then set during baking due to starch gelatinisation and coagulation of egg proteins [26]. Fat is typically used in biscuits to lubricate and coat the flour granules to prevent water absorption, and the development of starch and gluten in order to achieve a fine crumb (crumbly texture) and soft, tender mouthfeel [27]. Fat also contributes other important functions to cakes, biscuits and crackers such as flavour delivery and shelf life which is achieved through delaying water absorption by starch granules [28-31].

Fat replacers can be ingredients which are of carbohydrate, protein or fat origin, with many different types of fat replacers with different structures and functions within each group. We have not differentiated fat substitutes and fat mimetics in this review as the majority of fat replacers used in baked food products are fat mimetics. Instead, we have categorised fat replacers in this review as complex carbohydrate powders, gums and gels, whole food purees and products, or a combination thereof. This categorisation is based on their functional and industrial applications rather than their chemical properties.

(a) Complex carbohydrates are typically successful fat replacers due to their ability to bind water to form a paste which can mimic the texture and viscosity of fats in food products through providing lubricant or flow properties similar to fat in some food systems [28,32]. Examples of carbohydrate based fat replacers include inulin, maltodextrin and plant fibres.

(b) Gums and gels work similarly in function to complex carbohydrates, in that they bind with water to form gels which mimic the texture and viscosity of fats [28]. While some gums and gels are made up of complex carbohydrates, this is not specific as there are some protein- and fat-based 
gums and gels. Examples of gums and gels used as fat replacers include pectins, oleogels and whey protein.

(c) Whole foods are complete or partial food matrices that are included in a food product as fat replacers. Recently, many products have utilised whole foods such as fruits and vegetables, legumes or cereal based ingredients as fat replacers. These foods are typically successful due to their highly creamy texture when mashed or processed. Foods such as avocado can achieve this due to its oil composition, banana for its high starch content, and legumes for their high starch and protein contents.

(d) Combinations of the above fat replacers are useful as they can potentially replicate multiple sensory qualities of dietary fat. In addition, complexes formed from these combinations, such as emulsions and esters, may have a greater fat replacing effect than the sum of their parts.

\section{Summary of the Current Fat Replacers Used in Baked Products}

Complex carbohydrate fat replacers range from digestible starches to non-digestible plant fibres (Table 1). It should be noted that the replacement of dietary fat with complex carbohydrates reduced energy density of all the food products in Table 1, regardless of fibre status, due to complex carbohydrate being less energy dense than fat. The use of fibres instead of starches could have an advantage on the market, as foods may meet criteria for fibre content claims. Inulin, a non-digestible dietary fibre typically derived from chicory root, was observed to have the greatest success in replacing dietary fat in baked products, where a fat replacement (FR) level of up to $75 \%$ in legume crackers and cake (1:1, inulin: water; and 1:2 inulin: water, respectively) was able to reduce total energy without any changes in consumer acceptance $[33,34]$. It should be noted that the addition of inulin did change the textural and physical properties of the cracker and cake products. While acceptance was not measured for the use of inulin in muffins, 50\% FR had the least sensory and physical changes compared to $75 \%$ and $100 \%$ FR [35]. In addition, Zahn et al. tested the use of four commercial inulin formulations in muffins which varied in inulin to water ratio and solubility, but the outcomes for each were similar [35]. Maltodextrin was also successful at 75\% fat replacer level in legume crackers and at $66 \%$ FR in muffins, although there were changes noted in aroma, appearance, taste and texture $[33,36]$. Total FR of inulin or maltodextrin $(100 \%)$ had a significant decrease in consumer acceptance, so it is not recommended to fully replace fat in a baked food product. Results were also promising for inulin used as a fat replacer in biscuits, although there was some notable changes to textural and physical properties [33-35,37-39]. Other complex carbohydrates used as fat replacers in biscuits included lupine extract, maltodextrin, corn fibre, and rice starch, although all of these had significant effects on sensory properties of the biscuits except rice starch [33,36,40-43]. Rice starch has no significant effects on sensory properties, but was only tested at $20 \%$ FR. All complex carbohydrate fat replacers had a significant effect on the physical properties of doughs and their baked products, with significant increases in density, toughness, breaking strength, moisture, and decreases in volume for nearly all tested products [33-46].

Of all the complex carbohydrate fat replacers, inulin had the greatest success at reducing total fat and energy of the food product, with the least impact on sensory qualities and consumer acceptance, particularly in the legume crackers. Long chain inulin has the ability to form microcrystals which in turn aggregate together, interact with water, and eventually agglomerate creating a gel network [47]. To some extent, this gel network seems to have the ability to mimic the functions of fat in baked products such as being able to lubricate dry ingredients (through surrounding starch and protein), assisting in maintaining a shortening effect. Maltodextrin was also a successful fat replacer in legume crackers, although it was not as successful at replacing fat in biscuits compared to inulin. Inulin is also a good source of fibre, has promising gut health properties due to its prebiotic nature, and may increase absorption of nutrients such as calcium [48]. Moreover, inulin may benefit from marketing with fibre content claims, which may be appealing to consumers. Therefore, we recommend inulin as a reasonably high level fat replacer in crackers, cakes, biscuits and muffins [48]. 
Table 1. Summary of quality changes of complex carbohydrate fat replacers in baked food products.

\begin{tabular}{|c|c|c|c|}
\hline Fat Replacer & Food(s) & FR Tested & Quality Changes \\
\hline Inulin & $\begin{array}{l}\text { Cake [34] } \\
\text { Biscuit [37-39] } \\
\text { Muffin [35] }\end{array}$ & $\begin{array}{l}9.3-50 \% \\
35-100 \% \\
50-100 \%\end{array}$ & $\begin{array}{l}\text { Physical: } \downarrow \text { cell density, aW, volume; } \uparrow \text { breaking } \\
\text { strength, dough consistency, moisture, crumb density, } \\
\text { firmness, springiness; NSC cohesiveness } \\
\text { Sensory: } \downarrow \text { buttery flavour, crumbliness, acceptance } \\
\text { (100\% FR), embrowning (muffin: } 50 \%) \text {, open surface, } \\
\text { arched shape, typical smell, sweetness, typical taste; } \\
\uparrow \text { toasted flavour, chewiness, adhesiveness, } \\
\text { springiness (100\% FR), crispiness, crunchiness, } \\
\text { dryness, toughness hardness, glossiness; NSC } \\
\text { acceptance ( } 50-75 \% \text { FR) }\end{array}$ \\
\hline Lupine Extract & Biscuit [40] & $30-40 \%$ & $\begin{array}{l}\text { Physical: } \downarrow \text { volume, lightness; } \uparrow \text { breaking strength, } \\
\text { dough consistency, aW, moisture } \\
\text { Sensory: } \downarrow \text { sweetness; } \uparrow \text { firmness, dryness, chewing } \\
\text { time, roasted flavour }\end{array}$ \\
\hline Maltodextrin & $\begin{array}{l}\text { Biscuit [40,41] } \\
\text { Legume Cracker [33] } \\
\text { Muffin [36] } \\
\text { Croissant [42] }\end{array}$ & $\begin{array}{l}25-100 \% \\
66 \% \\
25-100 \%\end{array}$ & $\begin{array}{l}\text { Physical: } \downarrow \text { volume, spread ratio; } \uparrow \text { breaking strength, } \\
\text { dough consistency, aW, moisture, cohesiveness, } \\
\text { chewiness; NSC hardness, springiness } \\
\text { Sensory: } \downarrow \text { sweetness, overall flavour, aroma, colour, } \\
\text { appearance, texture, taste, flavor, overall acceptance } \\
\text { (muffin); } \uparrow \text { firmness, dryness, chewing time; NSC } \\
\text { acceptance (legumes cracker: } 50-75 \% \text { FR), mouthfeel }\end{array}$ \\
\hline Corn Fibre & Biscuit [40] & $30-40 \%$ & $\begin{array}{l}\text { Physical: } \downarrow \text { volume; } \uparrow \text { breaking strength, dough } \\
\text { consistency, aW, moisture } \\
\text { Sensory: } \downarrow \text { sweetness; } \uparrow \text { firmness, dryness, } \\
\text { chewing time }\end{array}$ \\
\hline Rice Starch & $\begin{array}{l}\text { Biscuit [43] } \\
\text { Muffin [43] }\end{array}$ & $\begin{array}{l}20 \% \\
20 \%\end{array}$ & $\begin{array}{l}\text { Physical: } \downarrow \text { volume, height (muffins); } \uparrow \text { thickness } \\
\text { (biscuit) } \\
\text { Sensory: NSC all sensory qualities }\end{array}$ \\
\hline Resistant Starch & Biscuit [34] & $40 \%$ & Physical: $\downarrow$ hardness; $\uparrow$ spread ratio \\
\hline Polydextrose & Biscuit $[41,45,46]$ & $11.5-50 \%$ & $\begin{array}{l}\text { Physical: } \uparrow \text { hardness, brittleness, aW, breaking } \\
\text { strength; } \downarrow \text { penetration distance, spread ratio [41] } \\
\text { Sensory: } \uparrow \text { hardness, } \downarrow \text { overall flavour, appearance, } \\
\text { texture, taste, acceptance, NSC colour }\end{array}$ \\
\hline
\end{tabular}

aW: Water activity; FR: Fat replacement; NSC: No significant change; $\downarrow$ : decrease; $\uparrow:$ increase.

Gum and gel fat replacers, while mostly being carbohydrates, also include lipid-based and protein-based gums and gels (Table 2). Some of these fat replacers may also increase suitability for nutrition content claims, such as sources of fibre or protein. Guar gum and xanthan gum had relatively little effect on the physical properties of the cake product when used as fat replacers [49]. While sensory measures were not compared to a control, both types of cakes were rated as acceptable with a greater acceptance in the cake containing xanthan gum, and 50\% FR was considered ideal [49]. Oatrim (a tasteless white powder derived from oats, comprised of amylodextrins and $5-10 \% \beta$-glucan soluble fiber; incorporated as a powder or gel), caused significant changes to the physical properties of cake, croissants and biscuits [50-52]. However, this did not appear to have any impact on the sensory properties of these foods, even at $100 \%$ FR. Pectin also caused significant changes to the physical properties of cake, croissants and biscuits, specifically increasing the hardness and reducing the volume of these foods, which was paralleled by increased perception of hardness and reduced flavour from sensory evaluations $[42,46,53,54]$. This is notable as pectin was tested at a relatively low FR level in cake and biscuits (10-30\%), suggesting it is not an ideal fat replacer in baked products. Hydroxypropyl methylcellulose (HPMC) had significant effects on physical and sensory properties of crackers and biscuits, even at relatively low FR levels $[33,55]$. While consumer acceptance was not tested on crackers due to being considered unacceptable by a focus group [33], HPMC in biscuits was considered significantly less acceptable compared to control biscuits containing $18 \%$ canola oil suggesting it is also not an ideal fat replacer in these foods. 
Oleogels are products of solidifying vegetable oils using natural wax esters [56-59]. The oleogelation process forms waxy crystal structure which hold liquid oil within a solid matrix, which allows the use of liquid vegetable oils in place of shortening. While this does not necessarily reduce the total fat content of a food product, it is useful in reducing saturated fat content. It should be noted that all oleogels studies reviewed in this paper did reduce overall fat content of their tested foods [56-59]. However, oleogels were not successful as fat replacers in these studies as they made biscuit and cake denser and harder. Sensory properties seemed to be promising with an increase in taste and no difference in acceptance compared to the control foods. Lastly, whey protein was also not an ideal fat replacer for biscuits as it resulted in a decrease in overall flavour and acceptance [45,46].

Overall, gums and gels were not very successful as fat replacers in baked goods. Oatrim appeared to be the most successful as there were no significant changes to the sensory properties of cake and biscuits, although there were a large range of physical changes to these foods which might have an impact on industrial applications. Xanthan gum and guar gum might potential be useful fat replacers in cake as they had little impact on physical properties, although more robust sensory evaluations are needed in future studies.

Table 2. Summary of quality changes of gum and gel fat replacers in baked food products.

\begin{tabular}{|c|c|c|c|}
\hline Fat Replacer & Food(s) & FR Tested & Quality Changes \\
\hline Xanthan Gum & Cake [49] & $25-100 \%$ & $\begin{array}{l}\text { Physical: } \downarrow \text { volume (100\% FR), elasticity; } \uparrow \text { dough } \\
\text { density; NSC aW, firmness }\end{array}$ \\
\hline Guar Gum & Cake [49] & $25-100 \%$ & $\begin{array}{l}\text { Physical: } \downarrow \text { volume (100\% FR), elasticity; } \uparrow \text { dough } \\
\text { density; NSC aW, firmness }\end{array}$ \\
\hline Oatrim & $\begin{array}{c}\text { Cake }[50] \\
\text { Biscuit }[51,52]\end{array}$ & $20-60 \%$ & $\begin{array}{l}\text { Physical: } \downarrow \text { air bubbles, viscosity, spread ratio, } \\
\text { moisture, hardness (biscuits), brittleness; } \uparrow \text { specific } \\
\text { gravity, dough } \mathrm{pH} \text {, height, hardness (cake), } \\
\text { cohesiveness, springiness, aW } \\
\text { Sensory: NSC colour, appearance, tenderness, } \\
\text { sweetness, flavour, aftertaste, overall }\end{array}$ \\
\hline Pectin & $\begin{array}{l}\text { Cake [53] } \\
\text { Biscuit }[46,54] \\
\text { Croissant }[42]\end{array}$ & $\begin{array}{l}10-100 \% \\
25-100 \% \\
\end{array}$ & $\begin{array}{l}\text { Physical: } \downarrow \text { spread ratio, penetration distance, volume; } \\
\uparrow \text { weight, aW, breaking strength, specific gravity, } \\
\text { moisture, hardness } \\
\text { Sensory: } \uparrow \text { hardness, lightness, bitterness (biscuit: } \\
100 \%) ; \downarrow \text { overall flavour, acceptance, colour, texture, } \\
\text { cell size, taste, mouthfeel }\end{array}$ \\
\hline $\begin{array}{l}\text { Hydroxypropyl } \\
\text { Methylcellulose } \\
\text { (HPMC) }\end{array}$ & $\begin{array}{l}\text { Legume Cracker [33] } \\
\text { Biscuit [55] }\end{array}$ & $\begin{array}{l}25-100 \% \\
15-30 \% \\
\end{array}$ & $\begin{array}{l}\text { Physical: } \downarrow \text { lightness, yellowness; } \uparrow \text { moisture, } \\
\text { hardness, breaking strength; NSC aW } \\
\text { Sensory: } \uparrow \text { hardness, crispness; } \downarrow \text { overall acceptance, } \\
\text { yellowness, buttery flavour }\end{array}$ \\
\hline Oleogels & Biscuit [56] & $40-70 \%$ & $\begin{array}{l}\text { Physical: } \downarrow \text { spread ratio, breaking strength, specific } \\
\text { volume, fragmentation, porosity; } \uparrow \text { hardness, specific } \\
\text { gravity; NSC cell structure } \\
\text { Sensory: } \uparrow \text { hardness, chewiness, springiness, lightness } \\
\text { (crust), colour (crust), overall taste; } \downarrow \text { cohesiveness; } \\
\text { NSC overall smell, overall acceptability }\end{array}$ \\
\hline Whey Protein & Biscuit $[45,46]$ & $11.5-50 \%$ & $\begin{array}{l}\text { Physical: } \downarrow \text { hardness, weight; } \uparrow \text { aW; NSC spread ratio } \\
\text { Sensory: } \uparrow \text { hardness; } \downarrow \text { overall flavour, acceptance }\end{array}$ \\
\hline
\end{tabular}

aW: Water activity; FR: Fat reduction; NSC: No significant change; $\downarrow$ : decrease; $\uparrow:$ increase.

The interest in using whole food fat replacers has increased in recent years. These fat replacers are beneficial as they have a range of carbohydrates, lipids and proteins that may aid in the rheological properties of baked products, making them potentially more suitable than simple extracts and isolates. Overall, whole food fat replacers had the least effect on the physical and sensory properties of baked products, and in some cases increased the consumer acceptance (Table 3). Apricot kernel flour was a successful fat replacer with little impact on the physical and sensory properties of biscuits at a maximum of 50\% FR [60,61]. Chia seed mucilage also had little impact on physical properties of cake and bread up to $100 \%$ FR $[62,63]$, although sensory properties were not tested in these studies. 
High oleic sunflower oil (HOSO) did not significantly decrease the amount of total fat in biscuits, but did reduce the saturated fat content [64]. However, the use of HOSO as a fat replacer was not considered successful as it has significant impact on the volume, colour and texture of the biscuits. The use of avocado puree as a fat replacer in cake and biscuits was successful at $50 \%$ FR, as it did not impact consumer acceptance $[51,65]$. However, at 75-100\% FR, acceptance of the low-fat cake decreased compared to the control cake containing shortening [65]. Apple puree or pomace was the only whole food fat replacer to result in a reduction in sensory quality and consumer acceptance, even at low FR levels (10\%) [66,67]. Therefore, apple puree is not recommended as a fat replacer in biscuits. Bean puree and green pea puree had very similar effects on the sensory properties of biscuits with increases in sensory qualities at $25-75 \%$ FR $[68,69]$. The use of green pea puree at FR of $25 \%$ in biscuits was considered ideal, whereas a FR of $100 \%$ resulted in reduced consumer acceptance [69]. Lastly, a high $\beta$-glucan product derived from oats or oat bran had significant impact on texture, colour and moisture of biscuits $[45,54,70]$. Although sensory properties were not tested in these studies, this suggests that the high $\beta$-glucan product was not a successful replacer for shortening in biscuits.

Whole foods may be the most suitable candidates for fat replacers in baked foods as they appeared to have the least impact on physical and sensory properties. In addition, they may also be beneficial as they may contain phytochemicals and micronutrients which could increase the health benefits and marketing potential of baked foods products, leading to novel functional foods. Lastly, consumer are more likely to accept foods with ingredients or additives that are made from natural, whole food products [71]. Bean and pea purees were the most successful fat replacers for biscuits at $25-75 \%$ FR, and avocado puree was successful at reducing fat in cake at 50\% FR. However, more studies on whole food fat replacers in biscuits and bread is needed before they can be recommended as reliable fat replacers.

Table 3. Summary of quality changes of whole food fat replacers in baked food products.

\begin{tabular}{|c|c|c|c|}
\hline Fat Replacer & Food(s) & FR Tested & Quality Changes \\
\hline Apricot Kernel Flour & Biscuit $[60,61]$ & $10-50 \%$ & $\begin{array}{l}\text { Physical: } \downarrow \text { spread ratio, yellowness; } \uparrow \text { hardness, } \\
\text { lightnessSensory: NSC overall sensory score }\end{array}$ \\
\hline Chia Seed Mucilage & $\begin{array}{c}\text { Cake }[62,63] \\
\text { Bread }[63]\end{array}$ & $\begin{array}{l}25-100 \% \\
25-100 \%\end{array}$ & $\begin{array}{l}\text { Physical: } \downarrow \text { lightness, yellowness; } \uparrow \text { firmness; NSC volume, } \\
\text { symmetry, uniformity, redness, moisture, aW, breaking } \\
\text { strength }\end{array}$ \\
\hline $\begin{array}{l}\text { High Oleic Sunflower } \\
\text { Oil (HOSO) }\end{array}$ & Biscuit [64] & $100 \%$ & $\begin{array}{l}\text { Physical: } \downarrow \text { volume, moisture, lightness, yellowness; } \\
\uparrow \text { biscuit density, breaking strength, redness; NSC dough } \\
\text { density }\end{array}$ \\
\hline Avocado Puree & $\begin{array}{l}\text { Biscuit [51] } \\
\text { Cake [65] }\end{array}$ & $50-100 \%$ & $\begin{array}{l}\text { Physical: } \downarrow \text { spread ratio, moisture, stiffness, hardness; } \uparrow \text { aW, } \\
\text { brittleness } \\
\text { Sensory: } \downarrow \text { appearance, acceptance (75-100\%); NSC colour, } \\
\text { tenderness, sweetness, flavour, aftertaste, acceptance (50\%), } \\
\text { overall sensory score }\end{array}$ \\
\hline $\begin{array}{c}\text { Apple } \\
\text { Puree/Pomace }\end{array}$ & Biscuit $[66,67]$ & $10-100 \%$ & $\begin{array}{l}\text { Physical: } \downarrow \text { spread ratio, brittleness, hardness, yellowness; } \\
\uparrow \text { moisture } \\
\text { Sensory: } \downarrow \text { appearance, texture, chewiness, sweetness, } \\
\text { moistness }(100 \%) \text {, flavour, aftertaste, overall sensory score; } \\
\uparrow \text { moistness }(50 \%) \text {; NSC colour }\end{array}$ \\
\hline Bean Puree & Biscuit [68] & $25-75 \%$ & Sensory: $\uparrow$ appearance, colour, flavour, texture, acceptance \\
\hline Green Pea Puree & Biscuit [69] & $25-100 \%$ & $\begin{array}{l}\text { Physical: } \uparrow \text { moisture } \\
\text { Sensory: } \downarrow \text { flavour, aftertaste, acceptance }(100 \%) ; \uparrow \text { colour, } \\
\text { moistness, flavour ( } 25-75 \%) \text {, acceptance }(25 \%) \text {; NSC smell }\end{array}$ \\
\hline $\begin{array}{l}\text { Oat Bran/High } \\
\beta \text {-Glucan Oat } \\
\text { Product }\end{array}$ & Biscuit $[45,54,70]$ & $10-100 \%$ & $\begin{array}{l}\text { Physical: } \downarrow \text { spread ratio, hardness [59], redness, yellowness; } \\
\uparrow \text { hardness [37], brittleness, moisture, aW, lightness, volume }\end{array}$ \\
\hline
\end{tabular}


Fat replacers in combination with additional ingredients may provide better fat-like qualities as the additional ingredients are usually designed to supplement the unwanted effects of individual fat replacers, as seen above (Tables 1-3). These additional ingredients are usually other types of fat replacers, but can also be enzymes or emulsifiers. Few studies have assessed combined fat replacers in baked products, although the results appear promising (Table 4). Polydextrose and guar gum were successful fat replacers in biscuits at a relatively high level of FR $(70 \%)$, with an increase in perceived taste, flavour and consumer acceptance [72]. Maltodextrin and xanthan gum yielded increased moisture, hardness and chewiness in $66 \%$ FR muffins, but sensory analysis was not conducted in these samples [36]. Kel-Lite BK, a commercial fat replacer containing xanthan gum, guar gum, cellulose gel, sodium stearoyl lactylate, gum Arabic, dextrin, lecithin, and mono- and diglyceride, resulted in increased bitterness and, oddly increased both crumb firmness and softness in biscuits at $33 \%, 66 \%$ and $100 \%$ FR [54]. HOSO and inulin were also successful fat replacers in biscuits at 100\% FR [64,73], although HOSO does contain lipids so the biscuits only had reduced saturated fat rather than total fat. However, HOSO and inulin resulted in decreased appearance, flavour, odour, texture, and consumer acceptance in cakes, croissants and muffins [73]. Therefore, HOSO and inulin may only be suitable for use as fat replacers in biscuits. HOSO and $\beta$-Glucan may also be a useful fat replacer at $100 \%$ FR as this had little impact on physical properties in biscuits, although sensory evaluations were not conducted [64]. A combination of emulsion filled gel based on inulin and extra virgin olive oil (EVOO) has also been trialed as a fat mimetic in biscuits [74]. At 50\% FR, there were no changes to the physical properties and the overall consumer acceptance of the biscuit compared to the control biscuit containing $20 \%$ butter, although there was a decrease in overall flavour. However, consumer acceptance was not maintained at 100\% FR. Inulin, lipase and a commercial emulsifier ("Colco"; a type of alpha-gel emulsifier containing glycerol monostearate and polyglycerol esters of fatty acids) had little impact on physical properties of cake at $50-70 \%$ FR, although no sensory evaluation was conducted for this combined fat replacer either [75]. One study assessed the double, but not triple, combinations of corn fibre, maltodextrin and lupine extract in biscuits, each at 30-40\% FR [40]. All combinations had little impact on the physical properties of the biscuits compared to the control biscuit containing 33\% margarine. However, consumer preference for corn fibre and lupine extract was significant lower than the control, whereas corn fibre and maltodextrin was significant higher than the control [40]. This suggests that the combination of corn fibre and maltodextrin may be an ideal fat replacement in biscuits at a moderate FR level. Tapioca dextrin, tapioca starch and resistant starch as a combination fat replacer had an impact on a wide range of sensory properties in biscuits [76]. However, overall consumer acceptance decreased, even at relatively low FR levels (10-20\%), so we do not recommend the use of this combination fat replacer in biscuits.

Overall, combination fat replacers may be potential candidates for ingredients in low-fat baked products. The use of polydextrose and guar gum appears to be a reasonably effective fat replacer in biscuits. However, with the limited evidence currently available, recommendations cannot be made for the use of combination fat replacers in other baked products.

Table 4. Summary of quality changes of combined fat replacers in baked food products.

\begin{tabular}{cccl}
\hline Fat Replacer & Food(s) & FR Tested & \multicolumn{1}{c}{ Quality Changes } \\
\hline $\begin{array}{c}\text { Polydextrose and } \\
\text { Guar Gum }\end{array}$ & Biscuit [72] & $70 \%$ & $\begin{array}{l}\text { Physical: } \uparrow \text { spread ratio, hardness, stress-strain ratio, } \\
\text { moisture } \\
\text { Sensory: } \uparrow \text { overall taste, overall flavour, acceptance }\end{array}$ \\
\hline $\begin{array}{c}\text { Maltodextrin and } \\
\text { Xanthan Gum }\end{array}$ & Muffin [36] & $66 \%$ & $\begin{array}{l}\text { Physical: } \uparrow \text { aW, moisture, hardness, chewiness; } \downarrow \text { volume; } \\
\text { NSC springiness, cohesiveness }\end{array}$ \\
\hline Kel-Lite BK & Biscuit [54] & $33-100 \%$ & $\begin{array}{l}\text { Physical: } \uparrow \text { crumb firmness, crumb softness; NSC volume } \\
\text { Sensory: } \uparrow \text { bitterness }\end{array}$ \\
\hline
\end{tabular}


Table 4. Cont.

\begin{tabular}{|c|c|c|c|}
\hline Fat Replacer & Food(s) & FR Tested & Quality Changes \\
\hline HOSO and Inulin & $\begin{array}{l}\text { Biscuit }[64,73] \\
\text { Cake [73] } \\
\text { Croissant [73] } \\
\text { Muffin [73] }\end{array}$ & $100 \%$ & $\begin{array}{l}\text { Physical: NSC dough density, biscuit density, volume, } \\
\text { moisture, breaking strength, lightness, colour } \\
\text { Sensory: } \downarrow \text { appearance (croissant and muffin), odour } \\
\text { (croissant and muffin), texture (cake and croissant), flavour } \\
\text { (cake and muffin), acceptance (cake, croissant and muffin), } \\
\text { purchase intent (cake), preference (cake and muffin) }\end{array}$ \\
\hline HOSO and $\beta$-Glucan & Biscuit [64] & $100 \%$ & $\begin{array}{l}\text { Physical: } \downarrow \text { volume, lightness; } \uparrow \text { biscuit density; NSC dough } \\
\text { density, moisture, breaking strength, colour }\end{array}$ \\
\hline $\begin{array}{l}\text { EVOO and EFG based } \\
\text { on Inulin }\end{array}$ & Biscuit [74] & $50-100 \%$ & $\begin{array}{l}\text { Physical: } \downarrow \text { breaking strength }(100 \%) \text {, porosity }(100 \%) \text {; } \\
\text { Sensory: } \downarrow \text { caramel odour, buttery odour and flavour, } \\
\text { sweetness, crunchiness, crush, dryness, acceptance }(100 \%) \text {; } \\
\uparrow \text { consistency; NSC grain odour and flavour, saltiness }\end{array}$ \\
\hline $\begin{array}{l}\text { Inulin, Lipase and } \\
\text { Emulsifier }\end{array}$ & Cake [75] & $50-70 \%$ & $\begin{array}{l}\text { Physical: } \downarrow \text { batter density; } \uparrow \text { cohesiveness; NSC volume, cell } \\
\text { structure, hardness, chewiness, springiness }\end{array}$ \\
\hline $\begin{array}{c}\text { Corn Fibre, } \\
\text { Maltodextrin and/or } \\
\text { Lupine Extract }\end{array}$ & Biscuit [40] & $30-40 \%$ & $\begin{array}{l}\text { Physical: } \downarrow \text { lightness, volume; } \uparrow \text { breaking strength } \\
\text { Sensory: } \downarrow \text { preference (corn fibre and lupine extract); } \\
\uparrow \text { preference (corn fibre and maltodextrin) }\end{array}$ \\
\hline $\begin{array}{l}\text { Tapioca Dextrin, } \\
\text { Tapioca Starch and } \\
\text { Resistant Starch }\end{array}$ & Biscuit [76] & $10-20 \%$ & $\begin{array}{l}\text { Physical: } \downarrow \text { spread ratio; } \uparrow \text { breaking strength } \\
\text { Sensory: } \downarrow \text { buttery taste, crunchiness, hardness, colour, } \\
\text { buttery odour, appearance, texture, taste, sweetness, } \\
\text { acceptance; } \uparrow \text { shape homogeneity, floury taste, pastiness, } \\
\text { floury odour }\end{array}$ \\
\hline
\end{tabular}

aW: Water activity; FR: Fat reduction; NSC: No significant change; $\downarrow$ : decrease; $\uparrow$ : increase, HOSO: High Oleic Sunflower Oil; EVOO: Extra Virgin Olive Oil; EFG: Emulsion Filled Gel.

\section{Industry Recommendations and Conclusions}

It should be noted that there is limited literature on the use of fat replacers in low-fat baked products. Many of the reviewed fat replacers have only been assessed once, and also only in one type of food. There is a need for additional replicate studies using a variety of recipes. Also, while we have reviewed the current literature here, we cannot compare physical and sensory properties between studies. Therefore, while we can summarise which fat replacers were successful within a certain baked product, it is difficult to determine which fat replacer is best. In addition, the use of fat replacers in bread, muffins and croissants were only assessed in few studies each. Therefore, there is not enough information to make a recommendation of the best type of fat replacer for these products. Below is our recommendations for the best currently assessed fat replacers in a range of baked food products:

Biscuit-Oatrim was the most successful fat replacer in biscuits as it was able to retain most sensory properties of a traditional biscuit even at $100 \%$ FR, although there was a decrease in hardness and brittleness [51,52]. However, it should also be noted that both bean puree and green pea puree were able to increase the sensory qualities and consumer acceptance of biscuits at $75 \%$ FR with less of an impact on the physical properties compared to oatrim [68,69]. Legume purees might also have an advantage over oatrim as they may aid the marketability of food products due to potential nutrition claims such as vegetable and protein content. However, legume purees should not be used at $100 \%$ FR. Overall, we recommend the use of either oatrim or legume purees as fat replacers in biscuits.

Cake-Oleogels appeared to be the most successful fat replacer in cake, with no changes to the sensory qualities at 100\% FR [57-59]. However, there were significant changes to the physical properties of cake when using oleogels at FR levels $\geq 50 \%$ [58] which might lead to difficulty during cake production. An alternative could be avocado puree which was only successful at $50 \%$ FR but had less of an impact on the physical properties of cake [65], or inulin which was successful up to $75 \%$ FR but had an impact on the physical and textural properties of cake [34].

Cracker-While there was only one study on the use of fat replacers in crackers [33], it assessed and compared a range of fat replacers in the one study. Inulin appeared to be the most successful fat 
replacer in these crackers, reaching an acceptable level of FR at 75\%. The additional benefits of using inulin is that it may aid the marketability of food products due to potential high fibre claims.

Author Contributions: K.C. and A.C. collated the literature and wrote the manuscript. S.G. conceived the original idea, designed the format, reviewed the manuscript and provided critical feedback.

Funding: This research received no external funding.

Conflicts of Interest: The authors declare no conflict of interest.

\section{References}

1. World Health Organisation. Prevention of Cardiovascular Disease; World Health Organisation: Geneva, Switzerland, 2007.

2. Department of Health and Human Services, Department of Agriculture. 2015-2020 Dietary Guidelines for Americans, 8th ed.; Department of Health and Human Services: Washington, DC, USA, 2015.

3. Health Canada. Eating Well with Canada's Food Guide; Health Canada: Ottawa, ON, Canada, 2011.

4. National Health and Medical Research Council. Nutrient Reference Values for Australia and New Zealand Including Recommended Dietary Intakes; National Health and Medical Research Council: Canberra, Australia, 2006.

5. Public Health England. The Eatwell Guide; Public Health England: London, UK, 2016.

6. Hooper, L.; Abdelhamid, A.; Bunn, D.; Brown, T.; Summerbell, C.D.; Skeaff, C.M. Effects of total fat intake on body weight. Cochrane Database Syst. Rev. 2015, 8, CD011834. [CrossRef] [PubMed]

7. Aune, D.; Sen, A.; Prasad, M.; Norat, T.; Janszky, I.; Tonstad, S.; Romundstad, P.; Vatten, L.J. BMI and all cause mortality: Systematic review and non-linear dose-response meta-analysis of 230 cohort studies with 3.74 million deaths among 30.3 million participants. BMJ 2016, 353, i2156. [CrossRef] [PubMed]

8. Ng, M.; Fleming, T.; Robinson, M.; Thomson, B.; Graetz, N.; Margono, C.; Mullany, E.C.; Biryukov, S.; Abbafati, C.; Abera, S.F.; et al. Global, regional, and national prevalence of overweight and obesity in children and adults during 1980-2013: A systematic analysis for the Global Burden of Disease Study 2013. Lancet 2014, 384, 766-781. [CrossRef]

9. Whitlock, G.; Lewington, S.; Sherliker, P.; Clarke, R.; Emberson, J.; Halsey, J.; Qizilbash, N.; Collins, R.; Peto, R. Body-mass index and cause-specific mortality in 900,000 adults: Collaborative analyses of 57 prospective studies. Lancet 2009, 373, 1083-1096. [PubMed]

10. Abdullah, A.; Peeters, A.; de Courten, M.; Stoelwinder, J. The magnitude of association between overweight and obesity and the risk of diabetes: A meta-analysis of prospective cohort studies. Diabetes Res. Clin. Pract. 2010, 89, 309-319. [CrossRef] [PubMed]

11. Renehan, A.G.; Tyson, M.; Egger, M.; Heller, R.F.; Zwahlen, M. Body-mass index and incidence of cancer: A systematic review and meta-analysis of prospective observational studies. Lancet 2008, 371, 569-578. [CrossRef]

12. Bucher, T.; Collins, C.; Rollo, M.E.; McCaffrey, T.A.; De Vlieger, N.; Van der Bend, D.; Truby, H.; Perez-Cueto, F.J. Nudging consumers towards healthier choices: A systematic review of positional influences on food choice. Br. J. Nutr. 2016, 115, 2252-2263. [CrossRef] [PubMed]

13. Krystallis, A.; Chrysochou, P. Do health claims and prior awareness influence Consumers' preferences for unhealthy foods? The case of functional Children's snacks. Agribusiness 2012, 28, 86-102. [CrossRef]

14. Pearson, N.; Biddle, S.J. Sedentary behavior and dietary intake in children, adolescents, and adults. Am. J. Prevent. Med. 2011, 41, 178-188. [CrossRef] [PubMed]

15. Piernas, C.; Popkin, B.M. Trends in snacking among US children. Health Aff. 2010, 29, 398-404. [CrossRef] [PubMed]

16. Forbes, S.L.; Kahiya, E.; Balderstone, C. Analysis of snack food purchasing and consumption behavior. J. Food Prod. Market. 2016, 22, 65-88. [CrossRef]

17. Chandon, P.; Wansink, B. Does food marketing need to make us fat? A review and solutions. Nutr. Rev. 2012, 70, 571-593. [CrossRef] [PubMed]

18. Block, G. Foods contributing to energy intake in the US: Data from NHANES III and NHANES 1999-2000. J. Food Composit. Anal. 2004, 17, 439-447. [CrossRef]

19. Frye, A.M.; Setser, C.S. Optimizing texture of reduced-calorie yellow layer cakes. Cereal Chem. 1992, 69, 338-343. 
20. Drewnowski, A.; Nordensten, K.; Dwyer, J. Replacing sugar and fat in biscuits: Impact on product quality and preference. Food Qual. Prefer. 1998, 9, 13-20. [CrossRef]

21. Siro, I.; Kapolna, E.; Kapolna, B.; Lugasi, A. Functional food. Product development, marketing and consumer acceptance-A review. Appetite 2008, 51, 456-467. [CrossRef] [PubMed]

22. Tepper, B.J.; Trail, A.C. Taste or health: A study on consumer acceptance of corn chips. Food Qual. Pref. 1998, 9, 267-272. [CrossRef]

23. Hamilton, J.; Knox, B.; Hill, D.; Parr, H. Reduced fat products-consumer perceptions and preferences. Br. Food J. 2000, 102, 494-506. [CrossRef]

24. Richard, D.M. Position of the American Dietetic Association fat replacer. J. Am. Diet. Assoc. 1998, 98, 463-468.

25. Akoh, C.C. Fat replacers. Food Technol. 1998, 52, 47-53.

26. Wilderjans, E.; Luyts, A.; Brijs, K.; Delcour, J.A. Ingredient functionality in batter type cake making. Trends Food Sci. Technol. 2013, 30, 6-15. [CrossRef]

27. Maache-Rezzoug, Z.; Bouvier, J.M.; Allaf, K.; Patras, C. Effect of principal ingredients on rheological behaviour of biscuit dough and on quality of biscuits. J. Food Eng. 1998, 35, 23-42. [CrossRef]

28. Lucca, P.A.; Tepper, B.J. Fat replacers and the functionality of fat in foods. Trends Food Sci. Technol. 1994, 5, 12-19. [CrossRef]

29. Berenzon, S.; Saguy, I.S. Oxygen absorbers for extension of crackers shelf-life. LWT-Food Sci. Technol. 1998, 31, 1-5. [CrossRef]

30. Manley, D. Manley's Technology of Biscuits, Crackers and Biscuits; Woodhead Publishing: Cambridge, UK, 2011.

31. Nasir, M.; Butt, M.S.; Anjum, F.M.; Sharif, K.A.; Minhas, R. Effect of moisture on the shelf life of wheat flour. Int. J. Agric. Biol. 2003, 5, 458-459.

32. Voragen, A.G. Technological aspects of functional food-related carbohydrates. Trends in Food Sci. Technol. 1998, 9, 328-335. [CrossRef]

33. Colla, K.; Gamlath, S. Inulin and maltodextrin can replace fat in baked savoury legume snacks. Int. J. Food Sci. Technol. 2015, 50, 2297-2305. [CrossRef]

34. Rodríguez-García, J.; Puig, A.; Salvador, A.; Hernando, I. Optimization of a sponge cake formulation with inulin as fat replacer: Structure, physicochemical, and sensory properties. J. Food Sci. 2012, 77, C189-C197. [CrossRef] [PubMed]

35. Zahn, S.; Pepke, F.; Rohm, H. Effect of inulin as a fat replacer on texture and sensory properties of muffins. Int. J. Food Sci. Technol. 2010, 45, 2531-2537. [CrossRef]

36. Khouryieh, H.A.; Aramouni, F.M.; Herald, T.J. Physical and sensory characteristics of no-sugar-added/low-fat muffin. J. Food Qual. 2005, 28, 439-451. [CrossRef]

37. Błońska, A.; Marzec, A.; Błaszczyk, A. Instrumental Evaluation of Acoustic and Mechanical Texture Properties of Short-Dough Biscuits with Different Content of Fat and Inulin. J. Texture Stud. 2014, 45, 226-234. [CrossRef]

38. Rodríguez-García, J.; Laguna, L.; Puig, A.; Salvador, A.; Hernando, I. Effect of fat replacement by inulin on textural and structural properties of short dough biscuits. Food Bioprocess Technol. 2013, 6, 2739-2750. [CrossRef]

39. Krystyjan, M.; Gumul, D.; Ziobro, R.; Sikora, M. The effect of inulin as a fat replacement on dough and biscuit properties. J. Food Qual. 2015, 38, 305-315. [CrossRef]

40. Forker, A.; Zahn, S.; Rohm, H. A combination of fat replacers enables the production of fat-reduced shortdough biscuits with high-sensory quality. Food Bioprocess Technol. 2012, 5, 2497-2505. [CrossRef]

41. Sudha, M.L.; Srivastava, A.K.; Vetrimani, R.; Leelavathi, K. Fat replacement in soft dough biscuits: Its implications on dough rheology and biscuit quality. J. Food Eng. 2007, 80, 922-930. [CrossRef]

42. Shouk, A.A.; El-Faham, S.Y. Effect of fat replacers and hull-less barley flour on low-fat croissant quality. Pol. J. Food Nutr. Sci. 2005, 14, 287-292.

43. Lee, Y.T.; Puligundla, P. Characteristics of reduced-fat muffins and biscuits with native and modified rice starches. Emir. J. Food Agric. 2016, 28, 311-316. [CrossRef]

44. Basman, A.; Ozturk, S.; Kahraman, K.; Koksel, H. Emulsion and pasting properties of resistant starch with locust bean gum and their utilization in low fat biscuit formulations. Int. J. Food Prop. 2008, 11, 762-772. [CrossRef]

45. Zoulias, E.I.; Oreopoulou, V.; Tzia, C. Textural properties of low-fat biscuits containing carbohydrate-or protein-based fat replacers. J. Food Eng. 2002, 55, 337-342. [CrossRef] 
46. Zoulias, E.I.; Oreopoulou, V.; Tzia, C. Effect of fat mimetics on physical, textural and sensory properties of biscuits. Int. J. Food Prop. 2000, 3, 385-397. [CrossRef]

47. Bayarri, S.; González-Tomás, L.U.; Hernando, I.; Lluch, M.A.; Costell, E. Texture perceived on inulin-enriched low-fat semisolid dairy desserts. Rheological and structural basis. J. Texture Stud. 2011, 42, 174-184. [CrossRef]

48. Shoaib, M.; Shehzad, A.; Omar, M.; Rakha, A.; Raza, H.; Sharif, H.R.; Shakeel, A.; Ansari, A.; Niazi, S. Inulin: Properties, health benefits and food applications. Carbohydr. Polym. 2016, 147, 444-454. [CrossRef] [PubMed]

49. Zambrano, F.; Despinoy, P.; Ormenese, R.C.; Faria, E.V. The use of guar and xanthan gums in the production of 'light'low fat cakes. Int. J. Food Sci. Technol. 2004, 39, 959-966. [CrossRef]

50. Lee, S.; Kim, S.; Inglett, G.E. Effect of shortening replacement with oatrim on the physical and rheological properties of cakes. Cereal Chem. 2005, 82, 120-124. [CrossRef]

51. Wekwete, B.; Navder, K.P. Effects of avocado fruit puree and oatrim as fat replacers on the physical, textural and sensory properties of oatmeal biscuits. J. Food Qual. 2008, 31, 131-141. [CrossRef]

52. Swanson, R.B.; Garen, L.A.; Parks, S.S. Effect of a carbohydrate-based fat substitute and emulsifying agents on reduced-fat peanut butter biscuits. J. Food Qual. 1999, 22, 19-29. [CrossRef]

53. Lim, J.; Ko, S.; Lee, S. Use of Yuja (Citrus junos) pectin as a fat replacer in baked foods. Food Sci. Biotechnol. 2014, 23, 1837-1841. [CrossRef]

54. Conforti, F.D.; Charles, S.A.; Duncan, S.E. Evaluation of a carbohydrate-based fat replacer in a fat-reduced baking powder biscuit. J. Food Qual. 1997, 20, 247-256. [CrossRef]

55. Laguna, L.; Primo-Martín, C.; Varela, P.; Salvador, A.; Sanz, T. HPMC and inulin as fat replacers in biscuits: Sensory and instrumental evaluation. LWT-Food Sci. Technol. 2014, 56, 494-501. [CrossRef]

56. Mert, B.; Demirkesen, I. Reducing saturated fat with oleogel/shortening blends in a baked product. Food Chem. 2016, 199, 809-816. [CrossRef] [PubMed]

57. Kim, J.Y.; Lim, J.; Lee, J.; Hwang, H.S.; Lee, S. Utilization of oleogels as a replacement for solid fat in aerated baked goods: Physicochemical, rheological, and tomographic characterization. J. Food Sci. 2017, 82, 445-452. [CrossRef] [PubMed]

58. Amoah, C.; Lim, J.; Jeong, S.; Lee, S. Assessing the effectiveness of wax-based sunflower oil oleogels in cakes as a shortening replacer. LWT-Food Sci. Technol. 2017, 86, 430-437.

59. Pehlivanoglu, H.; Ozulku, G.; Yildirim, R.M.; Demirci, M.; Toker, O.S.; Sagdic, O. Investigating the usage of unsaturated fatty acid-rich and low-calorie oleogels as a shortening mimetics in cake. J. Food Process. Preserv. 2018, 42, e13621. [CrossRef]

60. Seker, I.T.; Ozboy-Ozbas, O.; Gokbulut, I.; Ozturk, S.; Koksel, H. Utilization of apricot kernel flour as fat replacer in biscuits. J. Food Process. Preserv. 2010, 34, 15-26. [CrossRef]

61. Özboy-Özbaş, Ö.; Seker, I.T.; Gökbulut, I. Effects of resistant starch, apricot kernel flour, and fiber-rich fruit powders on low-fat biscuit quality. Food Sci. Biotechnol. 2010, 19, 979-986. [CrossRef]

62. Felisberto, M.H.; Wahanik, A.L.; Gomes-Ruffi, C.R.; Clerici, M.T.; Chang, Y.K.; Steel, C.J. Use of chia (Salvia hispanica L.) mucilage gel to reduce fat in pound cakes. LWT-Food Sci. Technol. 2015, 63, 1049-1055. [CrossRef]

63. Fernandes, S.S.; de las Mercedes Salas-Mellado, M. Addition of chia seed mucilage for reduction of fat content in bread and cakes. Food Chem. 2017, 227, 237-244. [CrossRef] [PubMed]

64. Onacik-Gür, S.; Żbikowska, A.; Jaroszewska, A. Effect of high-oleic sunflower oil and other pro-health ingredients on physical and sensory properties of biscuits. CyTA-J. Food 2015, 13, 621-628. [CrossRef]

65. Nguyen, D.; Carotenuto, M.; Khan, S.; Bhaduri, S.; Ghatak, R.; Navder, K.P. Effect of Avocado Fruit Puree as Fat Replacer on the Physical, Textural and Sensory Properties of Shortened Cakes. J. Acad. Nutr. Diet. 2013, 113, A59. [CrossRef]

66. Min, B.; Bae, I.Y.; Lee, H.G.; Yoo, S.H.; Lee, S. Utilization of pectin-enriched materials from apple pomace as a fat replacer in a model food system. Bioresour. Technol. 2010, 101, 5414-5418. [CrossRef] [PubMed]

67. Hayek, S.A.; Ibrahim, S.A. Consumer acceptability of chocolate chip biscuits using applesauce as a fat (butter) substitute. Emir. J. Food Agric. 2013, 159-168.

68. Rankin, L.L.; Bingham, M. Acceptability of oatmeal chocolate chip biscuits prepared using pureed white beans as a fat ingredient substitute. J. Acad. Nutr. Diet. 2000, 100, 831-833. 
69. Romanchik-Cerpovicz, J.E.; Jeffords, M.J.; Onyenwoke, A.C. College student acceptance of chocolate bar biscuits containing puree of canned green peas as a fat-ingredient substitute. J. Culin. Sci. Technol. 2018. [CrossRef]

70. Lee, S.; Inglett, G.E. Rheological and physical evaluation of jet-cooked oat bran in low calorie biscuits. Int. J. Food Sci. Technol. 2006, 41, 553-559. [CrossRef]

71. Aschemann-Witzel, J.; Varela, P.; Peschel, A.O. Consumers' categorization of food ingredients: Do consumers perceive them as 'clean label' producers expect? An exploration with projective mapping. Food Qual. Prefer. 2019, 71, 117-128. [CrossRef]

72. Chugh, B.; Singh, G.; Kumbhar, B.K. Development of low-fat soft dough biscuits using carbohydrate-based fat replacers. Int. J. Food Sci. 2013, 2013, 576153. [CrossRef] [PubMed]

73. Doménech-Asensi, G.; Merola, N.; López-Fernández, A.; Ros-Berruezo, G.; Frontela-Saseta, C. Influence of the reformulation of ingredients in bakery products on healthy characteristics and acceptability of consumers. Int. J. Food Sci. Nutr. 2016, 67, 74-82. [CrossRef] [PubMed]

74. Giarnetti, M.; Paradiso, V.M.; Caponio, F.; Summo, C.; Pasqualone, A. Fat replacement in shortbread cookies using an emulsion filled gel based on inulin and extra virgin olive oil. LWT-Food Sci. Technol. 2015, 63, 339-345. [CrossRef]

75. Rodríguez-García, J.; Sahi, S.S.; Hernando, I. Functionality of lipase and emulsifiers in low-fat cakes with inulin. LWT-Food Sci. Technol. 2014, 58, 173-182. [CrossRef]

76. Laguna, L.; Varela, P.; Salvador, A.N.; Sanz, T.; Fiszman, S.M. Balancing texture and other sensory features in reduced fat short-dough biscuits. J. Texture Stud. 2012, 43, 235-245. [CrossRef]

(C) 2018 by the authors. Licensee MDPI, Basel, Switzerland. This article is an open access article distributed under the terms and conditions of the Creative Commons Attribution (CC BY) license (http:/ / creativecommons.org/licenses/by/4.0/). 